\title{
Left ventricular intracavitary microbubbles as evidence of non- thrombotic systemic embolization causing acute respiratory insufficiency and cerebrovascular symptoms
}

\author{
Ivo Planinc*, \\ Daniel Lovrić, \\ Dora Fabijanović, \\ Boško Skorić, \\ Hrvoje Jurin, \\ Jure Samardžić, \\ Nina Jakuš, \\ Jana Ljubas Maček, \\ Maja Čikes, \\ Davor Miličić
}

University of Zagreb School of Medicine, University Hospital Centre Zagreb, Zagreb, Croatia
RECEIVED:

March 11, 2017

ACCEPTED:

April 6, 2017

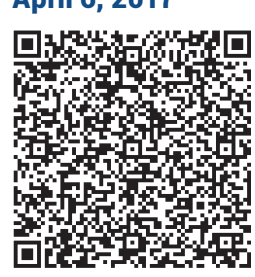

KEYWORDS: pulmonary embolism, respiratory insufficiency, glaucoma, echocardiography, microbubble. CITATION: Cardiol Croat. 2017;12(4):146. | https://doi.org/10.15836/ccar2017.146

*ADDRESS FOR CORRESPONDENCE: Ivo Planinc, Klinički bolnički centar Zagreb, Kišpatićeva 12, HR-10000 Zagreb, Croatia. / Phone: +385-1-2367-467 / E-mail: ivo.planinc@gmail.com

ORCID: Ivo Planinc, http://orcid.org/0000-0003-0561-6704 • Daniel Lovrić, http://orcid.org/0000-0002-5052-6559 Dora Fabijanović, http://orcid.org/0000-0003-2633-3439 • Boško Skorić, http://orcid.org/0000-0001-5979-2346 Hrvoje Jurin, http://orcid.org/0000-0002-2599-553X • Jure Samardžić, http://orcid.org/0000-0002-9346-6402 Nina Jakuš, http://orcid.org/0000-0001-7304-1127 • Jana Ljubas Maček, http://orcid.org/0000-0001-7171-2206 Maja Čikeš, http://orcid.org/0000-0002-4772-5549 • Davor Miličić, http://orcid.org/0000-0001-9101-1570

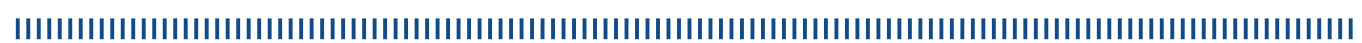
Introduction: Non-thrombotic pulmonary embolism (PE) is a rare cause of respiratory insufficiency (RI), and it may be caused by embolization of different cell types, foreign material or gas. ${ }^{1}$

Case report: 63-year old female who was surgically treated for left ocular intra-bulbar melanoma, and had silicon-oil instillation in the same eye had an episode of unexplained acute RI in November 2016 for which she was treated in a local hospital. In January 2017 she presented to emergency department of our hospital with eye pain associated with nausea and vomiting. Acute glaucoma was diagnosed, and she was treated with acetazolamide and mannitol. Approximately 2 hours later she became severely dyspnoeic and hypoxemic, and showed left sided hemiparesis. Due to progressive RI she was sedated, intubated, and mechanically ventilated. Bedside echocardiography revealed normal systolic function of normal sized LV, large amount of hyper-echogenic microbubbles in LV, and RV dilatation with signs of increased RV afterload with sPAP estimated to $50 \mathrm{mmHg}$. Thrombotic massive/submassive PE, ACS or other possible etiological factors were excluded. Initially, head CT did not show signs of cerebrovascular ischemia. In spite of maximum respiratory support delivered by mechanical ventilation ( $\mathrm{IPPV} \mathrm{FiO}_{2}$ 100\%, RR 25/min) ABG analysis revealed further progression of respiratory acidosis ( $\mathrm{pH} 7.1, \mathrm{pCO}_{2} 20 \mathrm{kPa}, \mathrm{pO}_{2} 7 \mathrm{kPa}$ ), and therefore decision was made to implant veno-arterial ECMO support. Before starting ECMO circuit the patient had to be resuscitated due to an episode of pulseless electrical activity. During the first $24 \mathrm{~h}$ after ECMO circuit initiation, echocardiography could still show persistence of hyper-echogenic LV microbubbles. During the first hospital day, physical exam also revealed abdominal and thoracic petechial rash. 3 days later the patient was successfully weaned off both ECMO support and mechanical ventilation. Follow-up head CT showed ischemic lesion in right frontal lobe. After prolonged hospital stay, the patient fully recovered, regained full motoric function of her left extremities, and was transferred to Rehabilitation Clinic.

Conclusion: Differential diagnosis of LV microbubbles with a triad of pulmonary distress, petechial rash and neurological symptoms includes inadvertent air insufflation during infusion handling, fat embolism, or fat-like embolism syndrome which could have been induced by silicon-oil derived from the eye.
LITERATURE IIIIIIIIIIIIIIIIIIIIIIIIIIIIIIIIIIIIIIIIIIIIIIIIIIIIIIIIIIIIIIIIIIIIIIIIIIIIIIIIIIIIIIIIIIIIIIIIIIIII

1. Jorens PG, Van Marck E, Snoeckx A, Parizel PM. Nonthrombotic pulmonary embolism. Eur Respir J. 2009 Aug;34(2):452-74. https://doi.org/10.1183/09031936.00141708 